\title{
Allozyme variation in two populations of the Mopane worm, Imbrasia belina (Saturniidae), and the effect of developmental stage and staggered generations
}

\author{
M. Greyling ${ }^{1}$, F. H. van der Bank ${ }^{1 \#}$, J. P. Grobler ${ }^{2}$ and D. C. J. Wessels ${ }^{3}$ \\ ${ }^{1}$ Department of Zoology, Rand Afrikaans University, P. O. Box 524, Auckland Park 2006, South Africa; ${ }^{2}$ Department \\ of Zoology and Biology and ${ }^{3}$ Department of Botany, University of the North, Private Bag X1106, Sovenga 0727, \\ South Africa
}

\begin{abstract}
Imbrasia belina is utilised as a food item by certain ethnic groups of southern Africa, but little is known of the genetic structure of this resource. The aims of this study were to determine whether the limited flight ability of moths has an effect on gene flow between two geographically distant I. belina populations, whether there are gene expression differences between moths, worms and pupae and whether staggered generations have different genotypic expressions. Gene products of 19 protein-coding loci from moths collected at two locations, one of which included two staggered generations, were analysed by horizontal starch gel electrophoresis. High levels of polymorphism (42\% and 47\%) and heterozygosity (0.182 to 0.210$)$ were present in all groups. There were developmental constraints on the expression of the phosphoglucomutase enzyme coding locus, and only allozyme and not isozyme differences between individuals from the various developmental stages were found at other loci. Although the groups displayed a large amount of variation, little differentiation and a large amount of gene flow were observed between them. Results indicate that the genetic diversity of I. belina populations is relatively high. The February-hatching Messina group is recommended for commercial utilisation due to the large amount of genetic variation in this population.
\end{abstract}

Keywords: Mopane worms, Imbrasia belina, genetic variation, genetic distance.

\# Author to whom correspondence should be addressed. E-mail: fhvdb@raua.rau.ac.za

\section{Introduction}

The immature stages of various closely-related Lepidoptera families have been used as supplementary food items in many parts of the world throughout human history, principally in Africa and Australia (Ohiokpehai et al., 1996). The caterpillars of various Emperor moth species are the most commonly utilised food insects of southern Africa (Marais, 1996). Mopane worms (Imbrasia belina Westwood, 1849) are particularly important as a trading item among certain ethnic groups in southern Africa (Marais, 1996).

The I. belina moth is widespread throughout southern Africa (Pinhey, 1975). Adult moths are large, short-lived (five days) and their fecundity can vary both temporally and spatially (Ditlhogo, 1996). The proboscis is reduced or vestigial and therefore I. belina does not feed as an adult (Pinhey, 1975). They tend to be clumsy fliers, and their flight patterns are probably affected by prevailing winds (Styles, 1994). During years of good rain, the distribution of Mopane worms will probably extend in the direction of the prevailing winds (Styles, 1994). The moths are nocturnal (both sexes fly at night, but the males only fly near midnight), remaining stationary during the day or hiding (Oberprieler, 1995). Their colouration camouflages them against the trunks of the Mopane trees (Colophospermum mopane), or they hide in the dense underbrush surrounding the trunk (Styles, 1994). Their colouration is extremely variable and can range from dark-brown to purple-red. This colour polymorphism is most likely a defence strategy to prevent predators from developing a search image for any particular morph (Oberprieler, 1995).

Imbrasia belina is bivoltine across most of its distribution, including Botswana and South Africa, in that it produces two generations per rainy season annually (Ditlhogo, 1996). It is only univoltine in the more arid areas (e.g. certain parts of Namibia) (Oberprieler, 1995). These staggered generations straddle two calendar years: the first generation is from October/November to December/January and the second generation is from February/March to April/May (Ditlhogo, 1996). The first generation reaches high abundance in Mopane woodland, although outbreak intensity varies both spatially and temporally (Gaston et al., 1997). Occasionally two generations may not be present, usually if rainfall has been poor or when the appearance of the first generation is delayed (Styles, 1994). It is not clear whether I. belina generations are 
merely staggered or represent different taxonomic groups. Farmers in the Northern Province are of the opinion that pupae from the December generation only hatch in December and pupae from the February generation only hatch in February. This suggests that there is no mixing of these two gene pools and that divergence into sub-species could occur.

The aims of this study were to determine: (a) whether the influence of limited flight ability has an effect on gene flow between two geographically distant I. belina populations, (b) whether there are gene expression differences between moths, worms and pupae and (c) whether staggered generations have different genotypic expressions.

\section{Materials and Methods}

Protein-coding loci in three groups of I. belina from the Mopane woodland area were analysed by horizontal starch gel electrophoresis. A total of $84 \mathrm{I}$. belina moths were sampled from Mopane trees at the following locations: 30 were obtained from the Messina Experimental Farm (22 ${ }^{\circ} 14^{\prime} \mathrm{S}$; $\left.29^{\circ} 55^{\prime} \mathrm{E}\right)$ during February 1999 (designated MEF'Feb) and 34 during November 1999 (MEF'Nov), and 20 were obtained

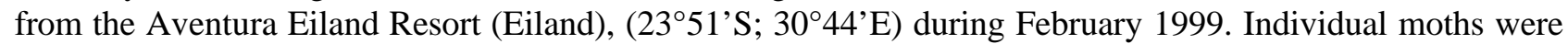
placed in cryotubes after removal of the wings, stored in liquid nitrogen $\left(-196^{\circ} \mathrm{C}\right)$ and transported to the laboratory. Moths were used because they do not feed and contamination with food products is thus minimised, and because moths represent a more random sample. Seven Mopane worms averaging $33 \mathrm{~mm}$ in

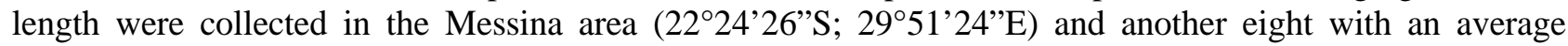
length of $74 \mathrm{~mm}$ were collected in another area $\left(22^{\circ} 25^{\prime} 47^{\prime \prime} \mathrm{S} ; 2^{\circ} 41^{\prime} 16^{\prime \prime} \mathrm{E}\right)$. The worms, moths and five pupa

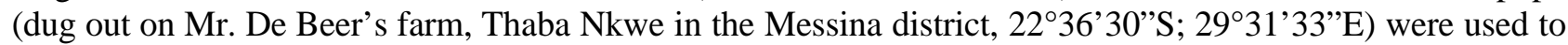
establish whether there are constraints to sampling a single developmental stage. Because of the unpredictability of moth and worm emergence, some of the samples were collected by farmers in the area and frozen $\left(-20^{\circ} \mathrm{C}\right)$ in plastic or paper packets.

Individual moths, worms and pupa were homogenised in distilled water $(1: 1 \mathrm{v} / \mathrm{v})$ and centrifuged at $10000 \mathrm{x} \mathrm{g}$ for 10 minutes. Twelve-percent starch gels were used to analyse samples. Electrophoretic procedures for horizontal starch gels were similar to those outlined by Hillis et al. (1996). Loci were labelled numerically starting from the most anodal locus. The alleles in each zone or locus were also labelled from the anode towards the cathodal end or buffer front according to the relative mobility of the gene products. The most common allele was designated $* 100$ and the other alleles were named relative to this position. Several buffer systems were used to separate proteins. Buffer AM was a continuous Tris, boric acid, EDTA and magnesium chloride buffer system (pH 8.6; Gonchurenko et al., 1992). Buffer RW was a discontinuous Tris, citric acid, lithium hydroxide-boric acid buffer system (gel $\mathrm{pH}$ 8.7, electrode $\mathrm{pH}$ 8.0; Ridgeway et al., 1970). Buffer PO was a discontinuous Tris, citric acid, sodium hydroxide-boric acid buffer system (gel $\mathrm{pH}$ 8.7, electrode $\mathrm{pH}$ 8.2; Poulik, 1957). Buffer HC was a discontinuous histidine-citrate buffer system (pH 5.7; Kephart, 1990).

Statistical analyses of allozyme data were done using the computer program BIOSYS-1 (Swofford \& Selander, 1981). Genetic variability within populations was analysed using average heterozygosity $(H)$, proportion of polymorphic loci $(\mathrm{P})$ and mean number of alleles per locus $(\mathrm{A})$ values. The chi-square $\left(\chi^{2}\right)$ goodness-of-fit test was performed using observed genotypes and those expected under Hardy-Weinberg equilibrium with Levene's (1949) formula for small sample size. Nei's (1972; 1978) genetic distances (D) were used to determine the degree of genetic differentiation between populations. Wright's fixation index (F) statistics $\left(\mathrm{F}_{\mathrm{IS}}, \mathrm{F}_{\mathrm{IT}}\right.$ and $\mathrm{F}_{\mathrm{ST}}$; Wright, 1965, 1978) are known as inbreeding coefficients (Ayala, 1982) and were used as additional measures of differentiation between populations (Swofford \& Selander, 1981; 1989). $\mathrm{N}_{\mathrm{em}}$ is known as the effective number of individuals exchanged between populations in each generation. The relationship between $\mathrm{F}_{\mathrm{ST}}$ and $\mathrm{N}_{\mathrm{em}}$ was calculated as $\mathrm{N}_{\mathrm{em}}=\left({ }^{1 /} \mathrm{F}_{\mathrm{ST}^{-}}-1\right) / 4 \alpha$ where $\alpha$ is the number of populations, and was used to establish the amount of gene flow between populations (Takahata, 1983). The unweighted pair-group method with arithmetic averaging (UPGMA) for cluster analysis and the DISWAG routines (Swofford \& Selander, 1981) were used to determine the relationship between the staggered generations and the different populations. DISPAN (Ota, 1993) was used to construct a phylogenetic tree using neighbourjoining and bootstrap tests (1000 replications), and BIOSYS-1 was used to determine genotypic differentiation by identifying loci that differ $\left(\mathrm{P}<0.05\right.$, contingency $\chi^{2}$ analyses $)$ between populations. 


\section{Results and Discussion}

Proteins stained for, locus abbreviations, enzyme commission numbers (E.C. no.) and buffers providing optimal results for I. belina are listed in Table 1 . Of the 28 enzymes stained for, 13 provided interpretable results. Enzymes that did not show sufficient activity or resolution for scoring were acid phosphatase (E.C. 3.1.3.2), alcohol dehydrogenase (E.C. 1.1.1.1), adenylate kinase (E.C. 2.7.4.3), esterase (E.C. 3.1.1.1), dihydrolipoamide dehydrogenase (E.C 1.8.1.4), glyceraldehyde-3-phosphate dehydrogenase (E.C. 1.2.2.12), L-lactate dehydrogenase (E.C. 1.1.1.27), malic enzyme (E.C. 1.1.1.38), menadione reductase (E.C. 1.6.99.-), nucleoside phosphorylase (E.C. 2.4.2.1), peroxidase (E.C. 1.11.1.7), 6-phosphogluconate dehydrogenase (E.C 1.1.1.44), sorbitol dehydrogenase (E.C 1.1.1.14) and shikimate dehydrogenase (E.C. 1.1.1.25). The protein products of AAT-2, MDH, PT-3 and SOD migrated cathodally, but Riddoch \& Solomon (1996) mentioned no cathodally migrating loci in a study of the same species.

Table 1 Proteins stained for, locus abbreviations, enzyme commission numbers (E.C. no.) and buffers used in this study

\begin{tabular}{llll}
\hline Protein & Locus & E.C. no. & Buffer \\
\hline Aspartate aminotransferase & AAT-1, -2 & 2.6 .1 .1 & AM \\
Creatine kinase & CK & 2.7 .3 .2 & AM \\
Glycerol-3-phosphate dehydrogenase & GPD & 1.1 .1 .8 & AM \\
Glucose-6-phosphate isomerase & GPI & 3.5 .1 .9 & RW \\
Hexokinase & HK & 2.7 .1 .1 & HC \\
Isocitrate dehydrogenase & IDH & 1.1 .1 .42 & HC \\
Leucine aminopeptidase (PEP-E) & LAP-1, -2 & $3.4 .11 / 13$ & RW \\
Malate dehydrogenase & MDH & 1.1 .1 .37 & HC \\
Peptidase-B (substrate: Leucyl-glycyl-glycine) & PEP-B1,-2 & $3.4 .11 / 13$ & AM \\
Peptidase-S (substrate: Leucyl-tyrosine) & PEP-S1,-2 & $3.4 .11 / 13$ & PO \\
Phosphoglucomutase & PGM & 5.4 .2 .2 & PO \\
General protein & PT-1,-2, -3 & & PO \\
Superoxide dismutase & SOD & 1.15 .1 .1 & AM \\
\hline
\end{tabular}

The loci used in this study included several that were reported to display good resolution and allelic variation in the study of Riddoch \& Solomon (1996). Several differences were observed between the present study and that of Riddoch \& Solomon (1996) in respect of band definition between loci. At the AK locus they observed one polymorphic locus whereas we observed poor resolution at this locus. The MDH locus had two loci with very poor definition in the study of Riddoch \& Solomon (1996), whereas one monomorphic locus was found in the present study. Two polymorphic LAP loci where detected in the present study compared to one monomorphic locus in the study of Riddoch \& Solomon (1996).

Riddoch \& Solomon (1996) reported that there were no developmental constraints on the expression of loci studied by them, but we observed differences in resolution and expression of gene products between moths, worms and pupae. No heterozygotes were detected for the PEP-S1 locus in worms and pupae, whereas $40 \%$ of moths were heterozygous. The PGM locus was expressed in moths but no resolution was obtained in worm instars or pupae for this enzyme. The PGM enzyme is involved with glycogen synthesis and might play a role in energy metabolism in the moth. Enzyme expression between different developmental stages may therefore be limited by the function of allozymes in the development of the insect (Harvey, 1996). However, the genotype at the PGM locus can also affect the length of time for which individual moths could fly continuously, as in the case of Maniola jurtina (Goulson, 1993). This might also be the case for I. belina moths. Although there were allozyme differences between developmental stages for CK, GPD, PEP-B and -S, there were no isozyme differences.

Allele frequencies for polymorphic loci are given in Table 2. Observed genotypes deviated from expected Hardy-Weinberg proportions at all of the polymorphic loci, except HK and PGM (Table 3). It is most likely that sample size and the occurrence of rare alleles caused these deviations, as factors such as bottlenecking and founder effect are probably not relevant in this situation. For example, genotypes at the IDH locus conformed to expected values after pooling the two MEF generations. Bottlenecks and founder effects occur when a very small number of individuals breed to give rise to a new population. These individuals may have been isolated from their original populations by either geographic or other types of 
separation. There is no evidence that either of these mechanisms are applicable to the Mopane moths analysed in the present study. Deviations at the AAT-1 and LAP-1 loci were only present in MEF'Feb. This might be because only this group displayed an AAT-1*94 allele and it only occurred in one individual, and the LAP-1 locus had a higher expected heterozygosity than was observed (Table 3). GPD, GPI and PEP-S1 expression showed deviations only in the Eiland population. The GPD locus had a GPD*96 allele in two individuals, which was not present in the remaining groups. Differences between observed and expected heterozygosities at the GPI locus in the Eiland population probably caused the deviation at this locus. The PEP-S1 locus had a much higher expected heterozygosity than observed (Table 3 ) and the PEPS-1*100 allele frequency was slightly lower than in the remaining groups (Table 2). No heterozygotes were observed at the HK or LAP-1 loci in the MEF'Nov group. The frequencies of the *100 allele in the HK and LAP-1 loci in the MEF'Feb and Eiland groups are very high $(0.983 ; 0.826$ and $0.969 ; 0.750$, respectively) (Table 2), suggesting a trend towards fixation.

Table 2 Allele frequencies for polymorphic loci in different populations and generation groups of $I$. belina

\begin{tabular}{lrccc}
\hline Locus & Relative mobility & MEF'Feb & $\begin{array}{c}\text { Locality } \\
\text { MEF'Nov }\end{array}$ & Eiland \\
\hline AAT-1 & $* 100$ & 0.611 & 0.672 & 0.594 \\
& $* 97$ & 0.352 & 0.328 & 0.406 \\
GPD & $* 94$ & 0.037 & & \\
& $* 104$ & 0.333 & 0.412 & 0.412 \\
& $* 100$ & 0.667 & 0.588 & 0.441 \\
GPI & $* 96$ & & & 0.147 \\
& $* 102$ & 0.018 & 0.059 & \\
& $* 100$ & 0.741 & 0.676 & 0.711 \\
& $* 98$ & 0.241 & 0.250 & 0.263 \\
HK & $* 95$ & & 0.015 & 0.026 \\
& $* 100$ & 0.983 & 1.000 & 0.969 \\
IDH & $* 97$ & 0.017 & & 0.031 \\
& $* 104$ & 0.333 & 0.353 & 0.250 \\
LAP-1 & $* 100$ & 0.648 & 0.647 & 0.639 \\
& $* 96$ & 0.019 & & 0.111 \\
LAP-2 & $* 95$ & 0.826 & 1000 & 0.750 \\
& $* 103$ & 0.174 & & 0.250 \\
PEP-B1 & $* 100$ & 0.207 & 0.340 & 0.167 \\
& $* 100$ & 0.793 & 0.660 & 0.833 \\
PEP-S1 & $* 97$ & 0.611 & 0.796 & 0.868 \\
& $* 100$ & 0.389 & 0.204 & 0.132 \\
PGM & $* 97$ & 0.733 & 0.790 & 0.632 \\
& $* 103$ & 0.267 & 0.210 & 0.368 \\
& $* 100$ & 0.340 & 0.500 & 0.406 \\
& $* 98$ & 0.640 & 0.500 & 0.594 \\
\hline
\end{tabular}

Rare and scarce alleles could indicate that such individuals have an advantage under adverse conditions. If the allele conferred an advantage, selection against the remaining alleles would occur, but if it were detrimental, the opposite would occur. It is not clear whether the rare alleles detected in this study would be of benefit or not, or whether this is just a sampling variation effect. Rare alleles have, however, been discovered in other Lepidopteran studies and conspecific populations, for example in small ermine moths and the spruce budworm, Choristoneura fumiferana, where some populations are distinguished by rare alleles and allele frequency differences (Menken, 1982; Harvey, 1996). A similar observation was made in the fall armyworm (Spodoptera frugiperda) where the Puerto Rican population had an allele that was uncommon or rare in the mainland populations (Pashley et al., 1985). 
Table 3 Observed and expected heterozygosity, heterozygosity deficiency (indicated with -) or excess from expected Hardy-Weinberg proportions (d), $\chi^{2}$, and degrees of freedom (DF) values for polymorphic loci in two populations of I. belina

\begin{tabular}{|c|c|c|c|c|c|c|}
\hline Locus & Locality & $\begin{array}{c}\text { Observed } \\
\text { heterozygosity }\end{array}$ & $\begin{array}{c}\text { Expected } \\
\text { heterozygosity }\end{array}$ & d & $\chi^{2}$ & DF \\
\hline \multirow[t]{3}{*}{ AAT-1 } & MEF'Feb & 13 & 13.792 & -0.057 & $* 53.113$ & 3 \\
\hline & MEF'Nov & 15 & 14.333 & 0.047 & 0.072 & 1 \\
\hline & EILAND & 5 & 7.968 & -0.372 & 2.380 & 1 \\
\hline \multirow[t]{3}{*}{ GPD } & MEF'Feb & 8 & 12.226 & -0.346 & 3.384 & 1 \\
\hline & MEF'Nov & 20 & 16.716 & 0.196 & 1.354 & 1 \\
\hline & EILAND & 7 & 10.758 & -0.349 & $* 13.128$ & 3 \\
\hline \multirow[t]{3}{*}{ GPI } & MEF'Feb & 8 & 11.561 & -0.308 & 5.800 & 3 \\
\hline & MEF'Nov & 8 & 16.433 & -0.513 & 17.254 & 6 \\
\hline & EILAND & 3 & 8.297 & -0.638 & $* 11.254$ & 3 \\
\hline \multirow[t]{2}{*}{ HK } & MEF'Feb & 1 & 1.000 & 0.000 & 0.000 & 1 \\
\hline & $\begin{array}{l}\text { MEF'Nov } \\
\text { EILAND }\end{array}$ & 1 & 1.000 & 0.000 & 0.000 & 1 \\
\hline \multirow[t]{3}{*}{ IDH } & MEF'Feb & 12 & 12.887 & -0.069 & 2.068 & 3 \\
\hline & MEF'Nov & 22 & 15.761 & 0.396 & $* 5.521$ & 1 \\
\hline & EILAND & 3 & 9.571 & -0.687 & *29.439 & 3 \\
\hline \multirow[t]{2}{*}{ LAP-1 } & MEF'Feb & 4 & 6.756 & -0.408 & $* 4.296$ & 1 \\
\hline & $\begin{array}{l}\text { MEF'Nov } \\
\text { EILAND }\end{array}$ & 4 & 4.696 & -0.148 & 0.307 & 1 \\
\hline \multirow[t]{3}{*}{ LAP-2 } & MEF'Feb & 0 & 9.684 & -1.000 & $* 31.224$ & 1 \\
\hline & MEF'Nov & 5 & 11.449 & -0.563 & *8.344 & 1 \\
\hline & EILAND & 0 & 5.143 & -1.000 & $* 21.103$ & 1 \\
\hline \multirow[t]{3}{*}{ PEP-B1 } & MEF'Feb & 3 & 13.075 & -0.771 & $* 16.716$ & 1 \\
\hline & MEF'Nov & 5 & 8.925 & -0.440 & $* 5.662$ & 1 \\
\hline & EILAND & 5 & 4.459 & 0.121 & 0.341 & 1 \\
\hline \multirow[t]{3}{*}{ PEP-S1 } & MEF'Feb & 6 & 6.069 & -0.011 & 0.002 & 1 \\
\hline & MEF'Nov & 13 & 10.443 & 0.245 & 1.990 & 1 \\
\hline & EILAND & 2 & 9.081 & -0.780 & *12.299 & 1 \\
\hline \multirow[t]{3}{*}{ PGM } & MEF'Feb & 9 & 12.102 & -0.256 & 3.638 & 3 \\
\hline & MEF'Nov & 14 & 14.255 & -0.018 & 0.009 & 1 \\
\hline & EILAND & 5 & 7.968 & -0.372 & 2.380 & 1 \\
\hline
\end{tabular}

* Loci where deviations of allele combinations from expected Hardy-Weinberg proportions occurred (P < $0.05)$.

Significant deviations of allele classes from expected Hardy-Weinberg proportions may occur due to a wide variety of reasons, such as inbreeding, crossing and linking, sampling error, population bottlenecks and random genetic drift (Ayala, 1982). These factors can shift the equilibrium and disrupt the stability of populations, leading to changes in genetic structure or profile. Because of this, ideal Hardy-Weinberg populations do not actually occur in nature (Ayala, 1982). In an ideal Hardy Weinberg population, genotypic frequencies could be predicted on the basis of genotypes if random mating occurs in the population, a large (infinite) sample size is taken and where there is no random selection or mutation and migration in a population. It is obvious that such criteria are not found in nature. However, non-random mating and gene flow can be excluded in the present study since these processes generally affect all loci (Ayala, 1982).

Selection can be excluded as a cause of class frequency deviation since all of the groups studied represent natural populations and the Mopane worms are not harvested on a commercial scale at the locations sampled. Although local people do harvest for household use, this is not sufficient to destroy the whole population. Bottleneck sizes greater than or equal to two individuals are unlikely to have major effects 
on the genetic composition of a population (Pashley et al., 1985). This is particularly true for insects including I. belina that have relatively high individual heterozygosities. Thus, the founder effect and bottlenecks can be excluded. However, populations may be subject to adverse years (with less individuals) because of environmental factors such as low rainfall and predation. Some regions might just have one generation in low rainfall years or more than two in good rainfall years. Although pesticide is a problem in some areas of Mopane woodland, it does not seem to be a factor at the Messina Experimental farm or the Aventura Eiland resort. However, factors such as outside lighting and ultraviolet trapping devices may have small effects as artificial selection pressures.

In general, differences in allele frequencies can be found among populations in different parts of the distribution area of a particular species (Den Boer, 1978). If however, enough gene flow occurs through migration, the whole system can be regarded as one panmictic unit and similar allele frequencies can be expected throughout the area (Den Boer, 1978). Imbrasia belina moths have limited flight ability and the worms cannot migrate more than $1 \mathrm{~km}$. Gene flow through migration seems improbable, especially in populations that, in this case, are separated by approximately $170 \mathrm{~km}$. However, the results of this study (see below) indicate that a high amount of gene flow is occurring between populations. The differences in allele frequencies are probably due to the high variability of this species which is most probably caused by the environment or by sample variation. Thus, the abundance of genotypic variation in the species can be refined by selection on local adaptation (Futuyma et al., 1984).

The observed polymorphic loci had A-values of 1.53 in MEF'Nov, 1.68 in Eiland and 1.74 in MEF'Feb. The mean A-values for other Lepidoptera species ranges between 1.51 for the small ermine moth (Yponomeutidae; Menken, 1982) and 1.9-2.8 for the fall armyworm (Noctuidae; Pashley et al., 1985). The A-values observed in the present study fall within the range reported in these studies.

The H-values of 0.182 (MEF'Nov), 0.200 (MEF'Feb) and 0.201 (Eiland) fall within the range reported for other Lepidoptera species. Estimates of $\mathrm{H}$ for wild populations of 46 diploid insect species, based on at least 20 loci, range between 0.02 and 0.33 , and values for three Lepidoptera species were 0.061, 0.324 and 0.327 (Graur, 1985). Although $\mathrm{H}$ in this study is high relative to that of other organisms (Nevo, 1978), it falls well within the range of other Lepidopterans and is similar to that found in Colias philodice and Euphydryas chalcedona (Menken, 1982; Packer et al., 1998).

The $\mathrm{P}$ ( 0.95 criterion) values were $42 \%$ (MEF'Nov) and 47\% (Eiland and MEF'Feb). Values ranging from $20 \%$ to $86 \%$ have been reported in most animal populations for which large numbers of protein coding loci have been surveyed (e.g. Selander \& Johnson, 1973; Lewontin, 1974). Values of 44-50\% have been reported for Lepidoptera (Nevo, 1978). Values of 12-35\% have been reported for Yponomeuta species and values of 50-91.7\% have been reported for Noctuidae species (Menken, 1982; Pashley et al., 1985). The high level of variation observed in natural populations of I. belina compares well with other populations of Lepidoptera in the wild.

The $\mathrm{D}_{78}$ values are 0.003 between the staggered generations and between the MEF'Feb and Eiland groups, and 0.005 between MEF'Nov and Eiland (Table 4).

Table 4 Summary of F-statistics, genetic distance coefficients $\left(D_{72}\right.$ and $\left.D_{78}\right), N_{e m}$ values and group mean values for the combined analyses of all the populations and generations

\begin{tabular}{lllllll}
\hline Group pair & Mean $\mathbf{F}_{\text {IS }}$ & Mean $\mathbf{F}_{\text {IT }}$ & Mean $\mathbf{F}_{\text {ST }}$ & $\begin{array}{l}\mathbf{D}_{72} \\
\text { values }\end{array}$ & $\begin{array}{l}\mathbf{D}_{\text {78 }} \\
\text { values }\end{array}$ & $\mathbf{N}_{\text {em }}$ values \\
\hline $\begin{array}{l}\text { MEF'Feb and } \\
\text { MEF'Nov }\end{array}$ & 0.198 & 0.211 & 0.016 & 0.008 & 0.003 & 3.844 \\
$\begin{array}{l}\text { MEF'Feb and } \\
\begin{array}{l}\text { EILAND } \\
\text { MEF'Nov and }\end{array}\end{array}$ & 0.391 & 0.402 & 0.018 & 0.009 & 0.003 & 3.410 \\
$\begin{array}{l}\text { EILAND } \\
\text { Group mean }\end{array}$ & 0.274 & 0.290 & 0.023 & 0.011 & 0.005 & 2.655 \\
\hline
\end{tabular}

The $\mathrm{D}_{72}$ values were higher in all cases. A $\mathrm{D}$ value of less than 0.3 is indicative of conspecific populations (Thorpe \& Solé-Cava, 1994). The $\mathrm{D}_{78}$ values, therefore, fall well within the lower range of populations from the same species (Ayala, 1982). The low $\mathrm{D}_{78}$ values between the MEF and Eiland population (0.003 and 0.005$)$ indicate that these groups are local populations and that the February 
generations at the different localities are more related to each other than the staggered generations at the different localities. There seems thus to be no apparent association between the geographic distance and genetic heterogeneity. A similar result was obtained for M. jurtina where populations that were separated by $165 \mathrm{~km}$ were genetically similar (Goulson, 1993).

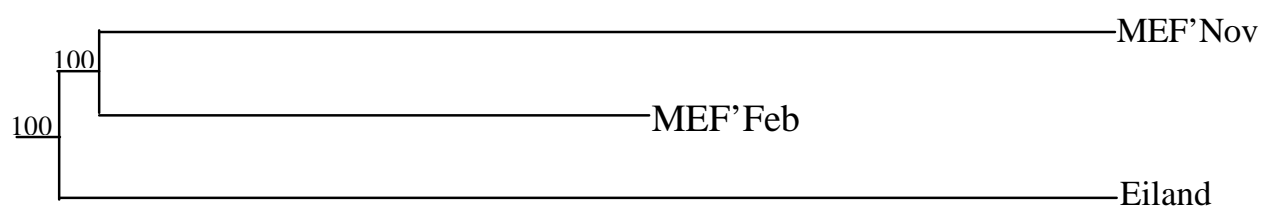

Figure 1 Phylogenetic tree depicting relationships within and between I. belina groups. Bootstrap numbers are listed at nodes

The dendrogram (Figure 1) obtained in the present study using DISPAN gives two groupings consisting of the Messina February and November generations, separated from the Eiland population (100\% bootstrap values). The amount of differentiation within groups shows that there is substantial differentiation in the MEF'Nov and Eiland groups, and approximately half of that in the MEF'Feb group. The phenetic relationships were also determined with BIOSYS-1, using $\mathrm{D}_{72}$ values and Cavalli-Sforza \& Edwards' (1967) chord distances (cophenetic correlation after optimisation $=100 \%$ ). The groupings were similar to those obtained with DISPAN.

F statistics (Table 4) can also be used to describe genetic differentiation between populations. The weighted average value for all polymorphic loci of $F_{I S}$ between all the groups (0.290) is indicative of a small amount of non-random mating occurring within each of the groups studied, because values that are close to zero indicate natural populations where random mating within sub-populations occurs (Nei, 1986). The mean $\mathrm{F}_{\mathrm{IT}}$ value between all groups (0.308) is relatively high. A possible explanation for this amount of inbreeding due to population subdivision could be that all moths do not emerge at the same time. These values compare favourably with values $\left(\mathrm{F}_{\mathrm{IS}}=0.158,0.202 ; \mathrm{F}_{\mathrm{IT}}=0.229,0.217\right)$ obtained for other Lepidoptera species (Pashley et al., 1985; Harvey, 1996). Wright (1978) suggested the following guidelines for the interpretation of $\mathrm{F}_{\mathrm{ST}}$ : the range from 0 to 0.05 indicates little genetic differentiation, 0.05 to 0.15 is indicative of moderate differentiation, 0.15 to 0.25 reflects great genetic differentiation, and very great genetic differences are present with values of more than 0.25. The highest $\mathrm{F}_{\mathrm{ST}}$ value was 0.023 (MEF'Nov and Eiland) and the lowest 0.016 (MEF'Feb and MEF'Nov) (Table 4). This indicates that the staggered generations (MEF populations) are 84\% similar and that the Eiland and MEF'Nov groups are genetically less similar (77\%). The mean $\mathrm{F}_{\mathrm{ST}}$ value of 0.025 between the polymorphic loci is indicative of little genetic differentiation between all the groups resulting from genetic drift. This is in agreement with the small D values. Population differentiation assessed by patterns of protein variation in I. belina groups compares well with that of A. gemmatalis (Velvet-bean caterpillars) (Pashley et al., 1985; Goulson, 1993; Harvey, 1996). $\mathrm{F}_{\mathrm{ST}}$ values for both of the above-mentioned species are in the mid range compared to other Lepidoptera. The number of loci and extent of overall range sampled can also influence $\mathrm{F}_{\mathrm{ST}}$ values between the above-mentioned species, and gross differences between them are likely to be meaningful. $\mathrm{F}_{\mathrm{ST}}$ values obtained in the present study, therefore, suggest interbreeding and an influx of immigrants among populations.

Genetic similarity between populations can be explained either by recent population fragmentation, or by gene flow between them (Pashley, 1985). Population fragmentation can be excluded from this study because of the high $\mathrm{N}_{\mathrm{em}}$ values of 3.844 (MEF'Feb and MEF'Nov), 3.410 (between MEF'Feb and Eiland) and 2.655 (between MEF'Nov and Eiland). An $\mathrm{N}_{\mathrm{em}}$ value of one is interpreted as evidence of sufficient gene flow between populations to counter the effects of genetic drift (Takahata, 1983). The high values obtained (Table 4) suggest that there is substantial gene flow between groups and could indicate that they have similar selective pressures. Gene flow may be reduced through physical barriers such as distance and historical differences in outbreak development, but it is difficult to ascertain whether this is the case with the I. belina groups analysed in this study. Distributions of I. belina seem to be plastic, changing yearly and mostly depend on regional rainfall patterns and wind direction. They generally move little further than from one host plant community to the next, because the moths are incapable of long-distance flight (Styles, 1994) and 
worms cannot disperse more than $1 \mathrm{~km}$. Consequently, migration over long distances can be excluded. The Mopane woodland belt stretches over thousands of kilometres and, although Mopane worms have a patchy distribution (Styles, 1996), it is likely that these populations are all connected. This would suggest that all of the populations could intermix as well as with the staggered generations, forming a huge panmictic unit (Den Boer, 1978) with similar selective pressures imposed on them. Another possible explanation may be afforded by the stepping stone pattern of gene flow where species move by tracking the progression of suitable resources (Peterson, 1996). This might indeed be the case in I. belina where resource use and drought conditions influence the distribution of the population and where the overall gene flow is greater than would be predicted from the dispersal biology of the species. Genetic studies on Euphilotes enoptes has provided evidence that indicates that gene flow, at least in sedentary insects, occurs over greater distances than are covered by dispersing individuals and that this spread of genes occurs in a stepping stone fashion (Peterson, 1996). Stepping stone gene flow is thus a homogenising force over large distances and such populations have the potential to influence the large-scale population genetic structure of sedentary species (Pieterson, 1996). These theories might explain the high amount of gene flow between the Messina staggered generations and the Eiland population.

Contingency $\chi^{2}$ analyses (Swofford \& Selander, 1981) were used to differentiate between all the studied groups at all loci. The PEP-B1 locus differentiates $(\mathrm{P}=0.035)$ between MEF'Feb and MEF'Nov because of the slightly higher $P E P-B I * 100$ allele frequency in the November generation. This was the only significant difference between the staggered generations, indicating (together with the small $\mathrm{D}$ and the $\mathrm{F}_{\mathrm{ST}}$ values) that they are genetically similar (as expected for individuals from the same population). Therefore, speculation that the staggered generations might represent sub-species is unfounded. The GPD $(\mathrm{P}=0.006)$ and PEP-B1 $(\mathrm{P}=0.007)$ loci as well as the total $(\mathrm{P}=0.035)$ averaged for all polymorphic loci differentiate significantly between MEF'Feb and Eiland. These differences are caused by the presence of the $G P D^{*} 96$ rare allele and the higher $P E P-B I * 100$ frequency in Eiland. Differentiation was observed between MEF'Nov and Eiland at GPD $(\mathrm{P}=0.004)$ and IDH $(\mathrm{P}=0.015)$ loci and the total averaged for all polymorphic loci $(\mathrm{P}=$ 0.003). This difference was caused by the lack of $G P D^{* 96}$ and $I D H * 96$ alleles in the MEF'Nov group. Despite significant differences at the above-mentioned loci, the overall genetic divergence between groups was relatively small because of the large amount of gene flow.

\section{Conclusion}

The results obtained in the present study provide baseline data that could be used to maintain sustainable levels of Mopane worm genetic variation. This data would be particularly useful for natural resource management programmes. Mopane worms could provide the rural communities in the Northern Province with an inexpensive and good quality food source, as well as a means of socio-economic upliftment. By way of example, 1600 tons of dried Mopane worms were sold in South Africa in 1982, which amounts to 780 million harvested I. belina caterpillars (Styles, 1995). In 1995 the Mopane worm industry in Botswana (still rudimentary and on a cash only basis) was believed to be worth about 4.42 million British pounds annually, while providing employment to 10000 people (Styles, 1995). Southern Africa, with explosive population growth, regular drought and recurrent food shortages, will likely remain an important consumer of these worms (Bartlett, 1996).

\section{Acknowledgements}

We thank Sasol for financial support.

\section{References}

Ayala, F.J., 1982. Population and Evolutionary Genetics: A Primer. The Benjamin / Cummings Publishing Company, Inc. Menlo Park, California, USA, 268.

Bartlett, E., 1996. Hold the turkey (the mopane worm as a food source). New Scientist 152, 58-59.

Cavalli-Sforza, L.L. \& Edwards, A.W.F., 1967. Phylogenetic analysis: models and estimation procedures. Evolution 21, 550-570.

Den Boer, M.H., 1978. Isoenzymes and migration in the African armyworm Spodoptera exempta (Lepidoptera, Noctuidae). J. Zool. 185, 539-553.

Ditlhogo, M., 1996. The ecology of Imbrasia belina (Westwood) in north-eastern Botswana. In: Proceedings of the first multidisciplinary symposium on phane. 18 June 1996. Eds. Gashe, B.A, Leggett, K \& Mpuchane, S.F. ISBN 99912-913-3-4, 46-68. 
Futuyma, D.J., Cort, R.P. \& Van Noordwijk, I., 1984. Adaptation to host plants in the fall cankerworm (Alsophila pometaria) and its bearing on the evolution of host affiliation in phytophagous insects. Am. Nat. 123(3), 287-296.

Gaston, K.J., Chown, S.L. \& Styles, C.V., 1997. Changing size and changing enemies: the case of the mopane worm. Acta Ecologica 18(1), 21-26.

Gonchurenko, G.G., Padutov, V.E. \& Silin, A.E., 1992. Population structure, gene diversity and differentiation in a natural population of cedar pines (Pinus subsect cembae, Pinaceae) in USSR. Plant Syst. Evol. 182, 121-134.

Goulson, D., 1993. Allozyme variation in the butterfly, Maniola jurtina (Lepidoptera: Satyrinae) (L.): evidence for selection. Heredity 71, 386-393.

Graur, D., 1985. Gene diversity in Hymenoptera. Evolution 39, 190-199.

Harvey, G.T., 1996. Population genetics of the Spruce budworm, Choristoneura fumiferana (Clem.) Freeman (Lepidoptera: Tortricidae), in relation to geographical and population density differences. Can. Entom. 128, 219-243.

Hillis, D.M., Moritz, C. \& Mable, B.K., 1996. Molecular systematics - Second Edition. Sinauer Associates, Inc. Publishers, Sunderland, Massachusetts, USA.

Kephart, S.R., 1990. Starch gel electrophoresis of plant isozymes: a comparative analysis of techniques. Am. J. Bot. 77, 693-712.

Levene, H., 1949. On a matching problem arising in genetics. Ann. Math. Stat. 20, 91-94.

Lewontin, R.C., 1974. The Genetic Basis of Evolutionary Change. Colombia University Press, New York, USA.

Marais, E., 1996. Omaungu in Namibia: Imbrasia belina (Saturniidae: Lepidoptera) as a commercial resource. In: Proceedings of the first multidisciplinary symposium on phane. 18 June 1996. Eds. Gashe, B.A, Leggett, K \& Mpuchane, S.F. ISBN 99912-913-3-4, 23-31.

Menken, S.B.J., 1982. Biochemical genetics and systematics of small ermine moths (Lepidoptera, Yponomeutidae). Z. Zool. Syst. Evolut.-forsch. 20, 131-143.

Nei, M., 1972. Genetic distance between populations. Am. Nat. 106, 283-293.

Nei, M., 1978. Estimation of average heterozygosity and genetic distance from a small number of individuals. Genetics. 89, 583-590.

Nei, M., 1986. Definition and estimation of fixation indices. Evolution. 40, 643-645.

Nevo, E., 1978. Genetic variation in natural populations: Patterns and theory. Theor. Popul. Biol. 13, 121177.

Oberprieler, R.G., 1995. The Emperor Moths of Namibia. Ecoguilde cc. Sigma Press, Pretoria, S. A. 91.

Ohiokpehai, O., Bulawayo, B.T., Mpotokwane, S., Sekwati, B. \& Bertinuson, A., 1996. Expanding the uses of phane, a nutritionally rich local food. In: Proceedings of the first multidisciplinary symposium on phane. 18 June 1996. Eds. Gashe, B.A, Leggett, K \& Mpuchane, S.F. ISBN 99912-913-3-4. pp. 84103.

Ota, T., 1993. DISPAN: Genetic distance and phylogenetic analysis. Pennsylvania State University, USA.

Packer, L., Taylor, J.S., Savignano, D.A., Bleser, C.A., Lane, C.P. \& Sommers, L.A., 1998. Population biology of an endangered butterfly, Lycaeides melissa samuelis (Lepidoptera; Lycaenidae): genetic variation, gene flow, and taxonomic status. Can. J. Zool. 76, 320-329.

Pashley, D.P., 1985. The use of population genetics in migratory studies: a comparison of three Noctuid species. In: Movement and dispersal of biotic agents. Eds. Barfield, C., Berger, R.D, Kennedy, G.G \& Mackenzie, D.R. Louisiana State University, Baton Rouge: pp. 305-324.

Pashley, D.P., Johnson, S.J. \& Sparks, A.N., 1985. Genetic population structure of migratory moths: the fall armyworm (Lepidoptera: Noctuidae). Ann. Entomol. Soc. Am. 78, 756-762.

Peterson, M.A., 1996. Long-distance gene flow in the sedentary butterfly, Euphilotes enoptes (Lepidoptera: Lycaenidae). Evolution. 50(5), 1990-1999.

Pinhey, E.C.G., 1975. Moths of southern Africa. Tafelberg Publishers Ltd. Cape Town, 273.

Poulik, M.D., 1957. Starch gel electrophoresis in a discontinuous system of buffers. Nature. 180, 1477-1479.

Riddoch, B.J. \& Solomon, J., 1996. Genetic variation in the mophane moth, Imbrasia belina. In: Proceedings of the first multidisciplinary symposium on phane. 18 June 1996. Eds. Gashe, B.A, Leggett, K \& Mpuchane, S.F. ISBN 99912-913-3-4, 14-22.

Ridgway, G., Sherburne, S.W. \& Lewis, R.D., 1970. Polymorphism in the esterases of Atlantic herring. Trans. Amer. Fish. Soc. 99, 147-151. 
Selander, R.K. \& Johnson, W.E., 1973. Genetic variation amongst vertebrate species. Ann. Rev. Ecol. Syst. $4,75$.

Styles, C.V., 1994. Mopane worms: more important than elephants? Farmer's Weekly. July 29, 14-16.

Styles, C.V., 1995. The elephant and the worm. BBC Wildlife. 13(3), 22-24.

Styles, C.V., 1996. The biological ecology of Imbrasia belina (Saturniinae, Saturniidae) with reference to its behaviour, physiology, distribution, population dynamics, impact within mopane veld and utilization within South Africa. In: Proceedings of the first multidisciplinary symposium on phane. 18 June 1996. Eds. Gashe, B.A, Leggett, K \& Mpuchane, S.F. ISBN 99912-913-3-4, 9-13.

Swofford, D.L. \& Selander, R.B., 1981. BIOSYS-1: A FORTRAN program for the comprehensive analysis of electrophoretic data in population genetics and systematics. J. Hered. 72, 281-283.

Swofford, D.L. \& Selander, R.B., 1989. BIOSYS-1: A computer program for the analysis of allelic variation in population genetics and biochemical systematics. Release 1.7. Illinois Natural History Survey, Illinois, 43.

Takahata, N., 1983. Gene identity and genetic differentiation of populations in the finite island models. Genetics. 104, 497-512.

Thorpe, J.P. \& Solé-Cava, A.M., 1994. Invited Review. The use of allozyme electrophoresis in invertebrate systematics. Zool. Scr. 23(1), 3-18.

Wright, S., 1965. The interpretation of population structure by F-statistics with special regard to systems of mating. Evolution. 19, 395-420.

Wright, S., 1978. Evolution and genetics of populations. Volume 4. Variation within and among natural populations. University of Chicago Press, Chicago, Illinois, 850. 